\title{
Zdeněk KLOS*, Jiř́i HAVLÍK** \\ CONTRIBUTION TO THE OPTIMAL DESIGN 3-STAGE GEARBOXES IN TERMS OF THE MINIMUM VOLUME OF THE GEARBOX
}

\author{
PŘÍSPĚVEK K OPTIMÁLNÍMU NÁVRHU 3-STUPŇOVÝCH PŘEVODOVEK Z HLEDISKA \\ MINIMÁLNÍHO OBJEMU SKŘÍNĚ PŘEVODOVKY
}

\begin{abstract}
Contribution is aimed to investigate the influence of design parameters facewidth ratio and helix angle of the teeth of individual gears on the optimal design of multistage gearboxes. The examination will be performed on 3-stage gearbox, which is optimized for minimum volume of the gearbox in software Matlab.
\end{abstract}

\begin{abstract}
Abstrakt
Příspěvek je zaměřen na vyšetření vlivu konstrukčních parametrů poměrné šiřrky a sklonu boku zubů ozubení na optimální navrhování vícestupňových převodů. Vyšetření bude provedeno na 3stupňové převodovce, která je optimalizována na minimální objem skříně převodovky v programu Matlab.
\end{abstract}

\section{INTRODUCTION}

The question of optimal design of multistage gearboxes is mainly focused on finding the optimal distribution of total transmission ratio of the partial ratios on individual stages. These distributions are optimized for a particular requirement, such as minimum length, volume, moment of inertia of gearbox, etc. Graphs and approximations describing this distribution are summarized in the literature, in transactions, web articles etc. The Fig.1.1 describes the optimal distribution of total transmission ratio of on partial 4-stage gearbox in terms of the minimum length of the gearbox, designed by $\mathrm{Vu}$ Ngoc Pi in [5].

This contribution focuses on the 3-stage gearbox designed in terms of minimum volume gearbox in the range of the total transmission ratio $\mathrm{u}_{\mathrm{C}}$ of 25 to 225 . It gives you the task to examine the effect of design parameters the facewidths ratio and the helix angle of the teeth of individual gears on the optimal design of the gearbox. For comparison, it is stated studies often the optimal distribution of total transmission ratio of on partial. Finally, contributions should be to determine what role they play these design parameters in design of 3-stage gearbox and multistage gearboxes in general in terms of the minimum volume of the gearbox.

\footnotetext{
* Ing. Zdeněk KLOS, VŠB - Technical University of Ostrava, Faculty of Mechanical Engineering, Department of Machine Parts and Mechanism, 17. listopadu 15/2172, 70833 Ostrava Poruba, tel. (+420) 597324313 , e-mail zdenek.klos.st@vsb.cz

** doc. Ing. Jiř́ HAVLÍK, Ph.D., VŠB - Technical University of Ostrava, Faculty of Mechanical Engineering, Department of Machine Parts and Mechanism, 17. listopadu 15/2172, 70833 Ostrava Poruba, tel. (+420) 59732 3284, e-mail jiri.havlik@vsb.cz
} 


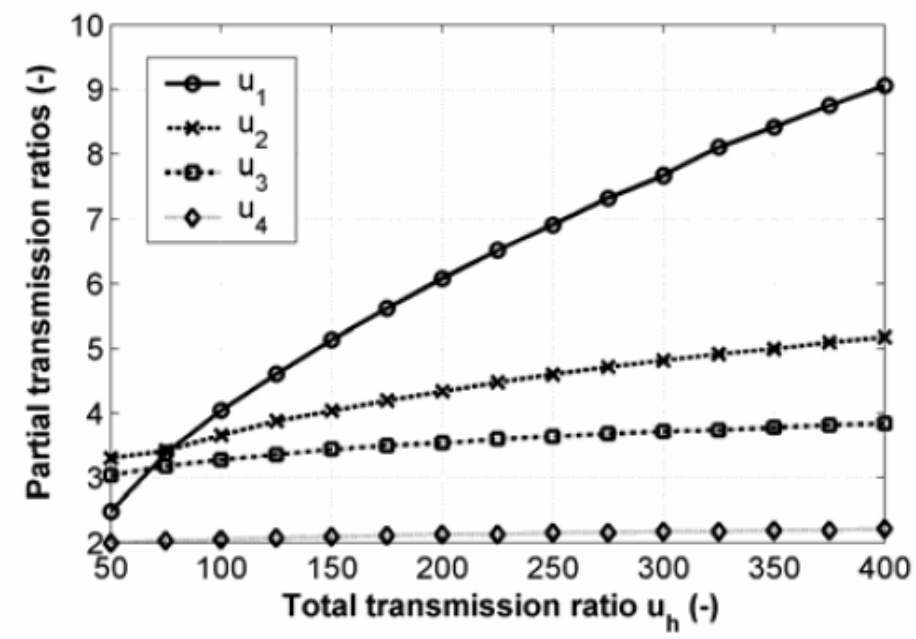

Fig. 1.1 Graph of optimal distribution of the total transmission ratio of on partial ratios 4-stage gearbox in terms of minimum length gearbox according to $\mathrm{Vu} \mathrm{Ngoc} \mathrm{Pi}$.

\section{DESCRIPTION OF CALCULATION MODEL}

For the purpose of the contribution is taken over a mathematical model of optimization task in [2] formed by the target function and constraints. This task is solved in software Matlab, see [4], with help function "fmincon", see [3]. Target function defines the role of the volume of the gearbox and is described by relations 2.1 to 2.4. Restrictive conditions define the role of existential, operational, technological and other constraints that must be respected in the design multistage gearboxes. Restrictive conditions presented in the contribution describe the common industry gearbox and are simply summarized as follows:

- all shaft axis lies in one plane,

- all gears have standard basic rack tooth profile by [1],

- application factor on all gears chosen $\mathrm{K}_{\mathrm{a}}=1.25$,

- $\quad$ safety coefficient for surface durability on all gears chosen $\mathrm{S}_{\mathrm{h}}=1.2$,

- the maximum ratio at one stage of chosen $u=10$,

- torque on the drive shaft chosen $\mathrm{T}=100 \mathrm{Nm}$,

- material all gears chosen alloy steel 14220 (DIN 16MnCr5) carburized hardened,

- the number of pinion teeth of all gears chosen 19 ,

- influence the effectiveness of gearing, bearings and wading included,

- included restrictions on interference between gears and shafts,

- overlap ratio of all gears chosen $\varepsilon_{\beta}=1.5$, to obtain approximate values total contact ratio $\varepsilon_{\gamma}$ $=3$,

- the addendum modification coefficient (ACM) on all gears is expected to use to the system balance specific sliding,

- the ratio of the pinion width to its diameter chosen $\psi_{\mathrm{d}}=0.9$.

Volume of gearbox $\left[\mathrm{mm}^{3}\right]$ :

$V=L \cdot H \cdot W$,

Length of gearbox [mm]:

$L=\frac{d_{a 1,1}}{2}+\left(\sum_{i=1}^{j=3} a_{i}\right)+\frac{d_{a 2,3}}{2}$,

Height gearbox [mm]:

$H=\max \left(\begin{array}{c}j=3 \\ d_{a 2, i} \\ i=1\end{array}\right)$, 
Width of gearbox $[\mathrm{mm}]$ :

$W=\max \left(b_{w i}^{j-1=3-1=2}+b_{w i+1}\right)$,

where:

$a_{i}-$ general centre distance $[\mathrm{mm}]$,

$b_{w i}-$ general common facewidht [mm],

$d_{a l, 1}$ - tip diameter of first pinion $[\mathrm{mm}]$,

$d_{a 2,3}$ - tip diameter of last wheel [mm],

$d_{a 2, i}$ - tip diameter of general wheel [mm],

$i \quad$ - general stage $[-]$,

$j \quad-$ number of stage [-].

\section{GRAPHIC EXPRESSIONS AND NUMERICAL INFLUENCE OF DESIGN}

\section{PARAMETERS}

The graphs in Fig. 3.1 to 3.3 are summarized sets of calculations optimal distribution of the total transmission ratio on the partial, facewidth ratio and helix angle of the teeth on all gears. In Tab. 1 these calculations are summarized as a power function approximations.

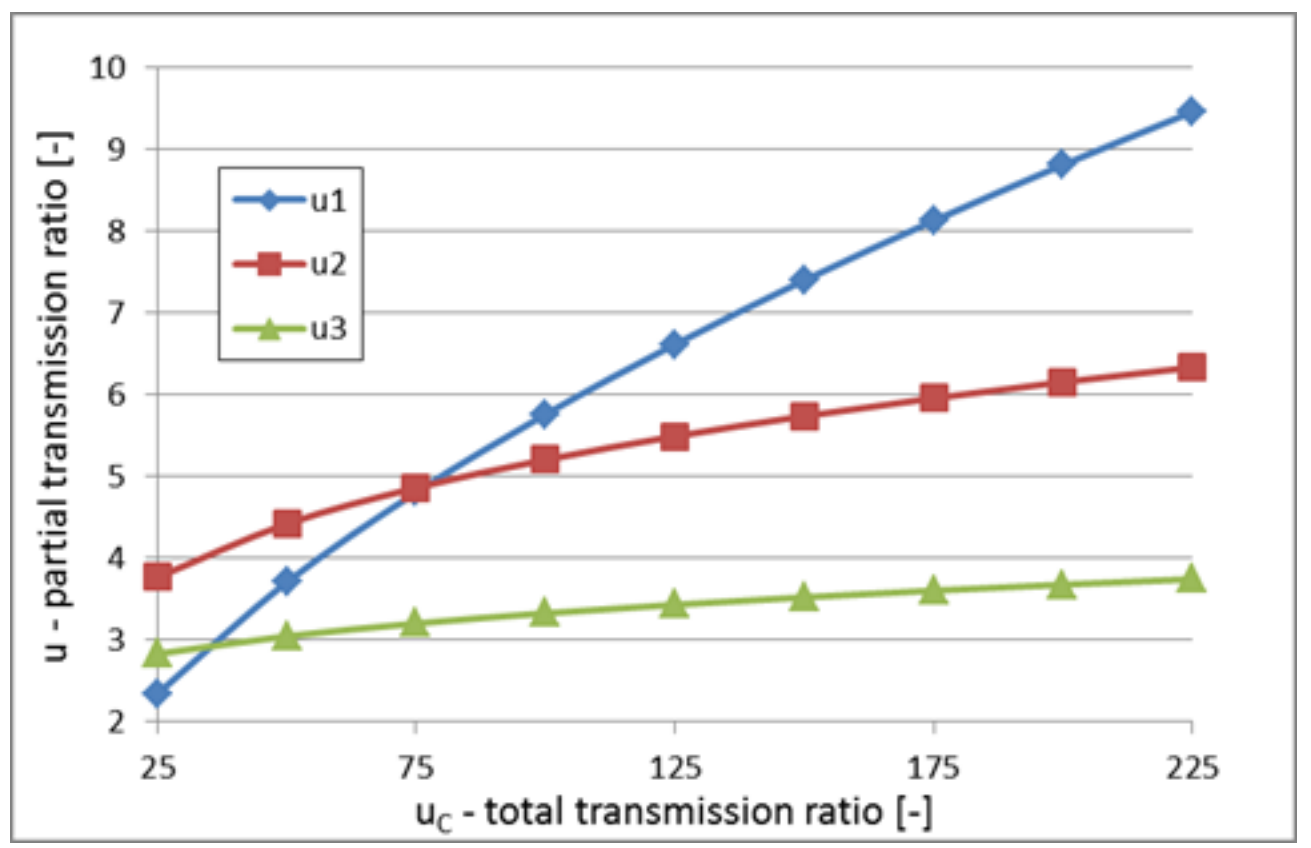

Fig. 3.1 Graph of optimal distribution of total transmission ratio of on partial ratios in terms of minimum volume 3 -stage gearbox. 


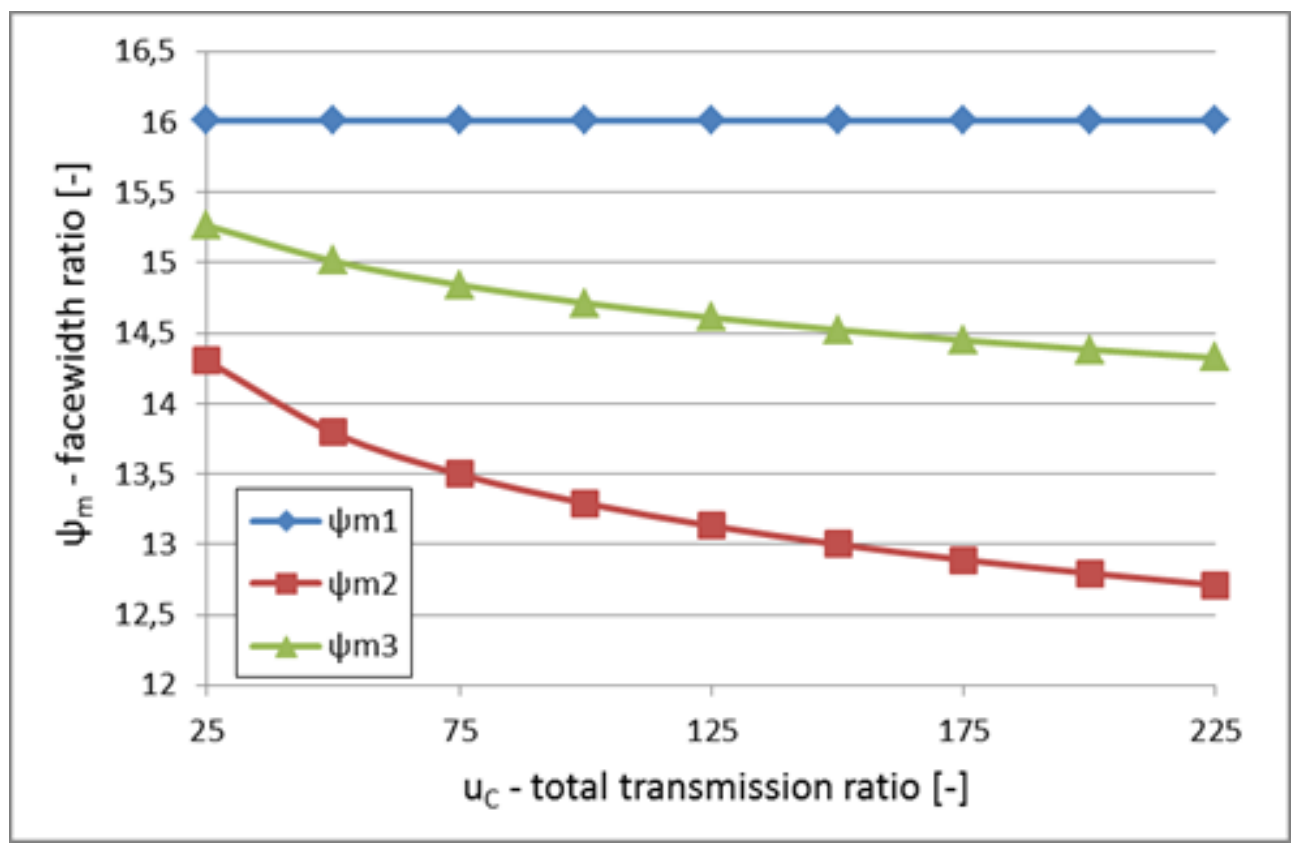

Fig. 3.2 Graph the optimal choice of the relative facewidth ratio of all gears in terms of minimum volume 3 -stage gearbox.

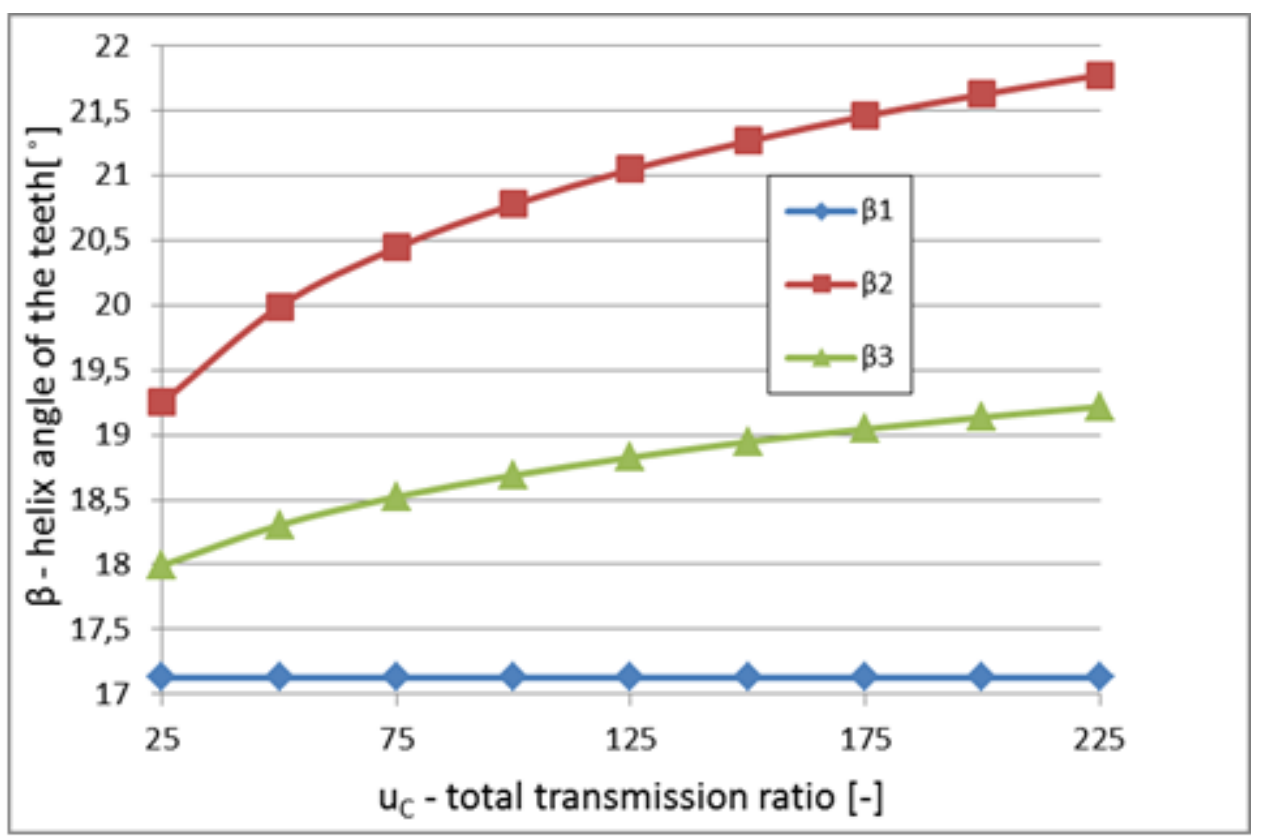

Fig. 3.3 Graph the optimal choice of helix angle of the teeth of all gears in terms of minimum volume 3-stage gearbox. 
Tab.1 Approximation table of design parameters.

\begin{tabular}{|c|c|c|c|c|c|}
\hline \multicolumn{2}{|r|}{ 1. stage } & \multicolumn{2}{|c|}{ 2. stage } & \multicolumn{2}{|c|}{ 3. stage } \\
\hline $\mathrm{u}_{1}[-]$ & $0,3077 \cdot u_{C}^{0,6344}$ & $\mathrm{u}_{2}[-]$ & $1,7516 \cdot u_{C}^{0,2369}$ & $\mathrm{u}_{3}[-]$ & $u_{C} / u_{1} \cdot u_{2}$ \\
\hline$\psi_{\mathrm{m} 1}[-]$ & $16^{*}$ & $\psi_{\mathrm{m} 2}[-]$ & $17,015 \cdot u_{C}^{-0,054}$ & $\psi_{\mathrm{m} 3}[-]$ & $16,808 \cdot u_{C}^{-0,029}$ \\
\hline$\beta_{1}\left[{ }^{\circ}\right]$ & $17,13^{*}$ & $\beta_{2}\left[{ }^{\circ}\right]$ & $16,054 \cdot u_{C}^{0,0561}$ & $\beta_{3}\left[{ }^{\circ}\right]$ & $16,289 \cdot u_{C}^{-0,0303}$ \\
\hline
\end{tabular}

*) a constant value

\section{USE IN DESIGN 3-STAGE GEARBOX}

The values summarized in the contribution can be used for designing 3-stage gearbox in terms of the minimum volume of the gearbox. The procedure is briefly summarized for the purposes of the contribution as follows:

1. total transmission ratio is divided into partial ratios by graphical or approximate dependence, is chosen the facewidth ratio and the helix angle of the teeth on all gears,

2. they determine the number of teeth of all gears, so that was adhered to the prescribed total transmission ratio,

3. they are intended for power, torque and speed for each shaft,

4. individual normal modules are designed for partial transfers,

5. is designed complete geometry to all transfers, the ACM on all gears is designed in to system balance specific sliding,

6. a check of interference between all gears and shafts, at the last step is necessary to know the preliminary diameter of the output shaft, it is designed in terms of allowable stress in the torsional, if they interference not be met, it is necessary to return to the geometric design and modify the center distance of individual partial transfers,

7. design of gearing is terminated, the following calculation of safety for all gears, if complying with the required amount of security coefficient, you must return to item 5 , and elect more or less normalized value of the normal module,

8. end.

\section{CONCLUSIONS}

For these graphs and approximations in the contribution shows that the choice of the facewidth ratio and helix angle of the teeth on all gears inclination play a role in the optimal design of multistage gearboxes in terms of the minimum volume of the gearbox.. However, this role is minor in comparison with the influence of the distribution of total transmission ratio on the partial. At the first stage, these values are even constant and at subsequent stages, there will only be a gradual change along the length of the interval changes of the total transmission ratio. For the designing a multistage gearboxes by reading from graphs and approximations is sufficient to know only the distribution of the total transmission ratio on the partial, without having committed major errors. But for truly optimized design of multistage gearboxes is a method of reading from graphs is insufficient, although often still widely used in practice. The best and most modern procedure is to perform design using specialized software and optimization of its own funds, which allow take into account the large number of design and technological parameters. 


\section{REFERENCES}

[1] ČSN 01 4686. Pevnostní výpočet čelních a kuželových ozubených kol. Praha: Vydavatelství Úřadu pro normalizaci a měření, 1989.

[2] KLOS, Zdeněk a Jiří HAVLÍK. Příspěvek $\mathrm{k}$ optimálnímu navrhování vícestupňových evolventních převodů z hlediska minimální délky. In: 51. medzinárodná vedecká konferencia katedier časti a mechanizmov strojov. Košice: C-PRESS, 2010, pp. 186-192. ISBN 978-80970-294-1-8.

[3] THE MATHWORKS, Inc. Fmincon [online]. [cit. 2012-03-12]. Available from WWW: http://www.mathworks.com/help/toolbox/optim/ug/fmincon.html.

[4] THE MATHWORKS, Inc. Matlab [online]. [cit. 2012-03-12]. Available from WWW: http://www.mathworks.com/products/matlab/.

[5] PI, Vu Ngoc. Optimal Calculation of Partial Transmission Ratios of Four-Step Helical Gearboxes for Getting Minimal Gearbox Length. In: World Academy of Science, Engineering and Technology [online]. 2008 [cit. 2012-03-19]. ISSN 2070-3724. Available from: http://www.waset.org/journals/waset/v37/v37-17.pdf 